\title{
Characteristic Quality of Pinrang's Cocoa Beans During Fermentation Used Styrofoam Containers
}

\author{
Erina Septianti ${ }^{1 *}$, Salengke ${ }^{1}$, Jumriah Langkong ${ }^{1}$, Nandi K. Sukendar ${ }^{1}$ and Arini Putri Hanifa ${ }^{2}$ \\ ${ }^{1}$ Department of Agriculture Technology, Faculty of Agriculture, Hasanuddin University, Indonesia \\ ${ }^{2}$ School of Agriculture and Environment, Massey University, New Zealand
}

\begin{abstract}
Pinrang Regency is one of the regencies that contributes the largest production in South Sulawesi. The fermentation process is the stage of processing cocoa beans that must be carried out to guarantee the taste and aroma of good chocolate. The purpose of research is to study the effect of fermentation time with different cocoa clones on the quality characteristics of cocoa beans during fermentation. Characterization was held by observing the shape and color of the cocoa beans visually and measuring the temperature, $\mathrm{pH}$, total acid, water content and fat content of the beans during fermentation. The results was showed that cocoa beans from local clones were better than Sulawesi 2 clones based on the quality characteristics of the beans produced. The best beans quality is on the 4 and 5 days of fermentation which produces an optimum temperature of around $45-47^{\circ} \mathrm{C}, \mathrm{pH}$ around $5-5.4$, total acid around $0.90 \%$. Cocoa beans with a physical appearance and color that is bright enough, fat content around $50.45 \%$, and the water content is quite low around $4.97 \%$. The quality of the cocoa beans produced is still in accordance with SNI 2323-2008. The use of styrofoam can be used as an alternative besides fermentation with wooden boxes that are usually done by farmers. The results of the study are expected to be used to obtain data and information on the characteristics of fermented cocoa beans, especially from Pinrang Regency, South Sulawesi.
\end{abstract}

\section{Article History}

Received February 19, 2020

Accepted June 21, 2020

\section{Keyword}

fermentation, cocoa, characteristic, cocoa clones, styrofoam

\section{Introduction}

South Sulawesi Province is the second largest of cocoa producing in Indonesia and distribution of cocoa in six districts, the one of them is in Pinrang district (1). However, as cocoa development areas are expanding, cocoa beans production and productivity have declined significantly. In addition to a smaller level of productivity compared to the potential of existing clones or planting material, the quality aspect also decreased (2).

Many factor significant influence the quality of cocoa products such as the raw material for cocoa beans and production process to produce cocoa products (3-5). The low quality of cocoa caused by the majority of cocoa national production not fermented. In general, cocoa farmers are reluctant to do fermentation because the selling price of cocoa is the same between fermented and unfermented cocoa beans. The another factor is the price of fermentation box very expensive and fermentation time need more time. The good quality of cocoa beans meaning seeds have been fermentation process before moving to another stage $(6,7)$. The quality of cocoa beans is a concern for consumers because cocoa beans used as raw material for food or drink (8). 
Fermentation is a very important and absolutely necessary stage of processing cocoa beans to prepare wet cocoa beans into high-quality dry beans that are suitable for consumption $(9,10)$. Perfect fermentation of cocoa beans will produce better flavor, aroma and color, because during fermentation the physical, chemical and biological changes occur in cocoa beans. These changes occur in pulp, seed coat and cotyledons (11-15). In addition improving and developing flavors, fermentation process also reduce bitter, deadly beans, improve the appearance of beans and facilitate subsequent handling $(6,16)$ such as removing pulp from beans, facilitating the release of beans shell from pod in the roasting process, inhibiting the germination process and beans coat becoming loose that facilitate the drying process easier $(17,18)$

Fermentation process used by several methods such as : heap fermentation, basket fermentation and fermentation in a box. Commonly box fermentation is containers made of wood or bamboo. However, it is also possible using other basic materials such as : styrofoam. Styrofoam can be used as an alternative because wood has a high price. In addition, styrofoam can conduct heat during the fermentation process (14). Some factors determine the success of fermentation include : the type of container, duration of fermentation, stirring frequency, variety, climate, fruit maturity, quantity of fermentation, dimensions and degree of aeration of the container and condition of yeast or bacteria that important factor in fermentation process (19-22).

Several types of cocoa clones/ varieties have been widely planted in Pinrang district are: Sulawesi 1, Sulawesi 2, 45, M01 and local clones. Sulawesi 2 clone is one of the cocoa clones that farmers like because they have large fruit and resistant from CPB (Cocoa Pod Borer), helopeltis spp. and PPR (Phytoptora Pod Rot) $(23,24)$. Ristanti et al. (25) stated that cocoa beans from Pinrang district had the highest fat content of $38.21 \%$. Fat content from other regions is only in the range of $20-27 \%$. The results of Ginting's research (26) showed that 4 days fermentation using a wooden box produced the best quality cocoa powder. However, research conducted by Putra et al.(27) and Aryani et al.(28) shows that the treatment of fermented cocoa beans in a wooden box for 6 days is a combination of treatments that produce cocoa powder with preferred flavor and the best characteristics of the cocoa seeds. In recent years, research on the fermentation and processing methods in order to quality processed cocoa products not yet development well especially result and publication research on the quality of fermented cocoa beans using styrofoam for cocoa beans from Pinrang district. The purpose of research is to study the effect of fermentation time with different cocoa clones on the quality characteristics of cocoa beans during fermentation.

\section{Materials and Methods}

The research support tools including : fermentation box based styrofoam measuring $75 \mathrm{~cm} \times 40 \mathrm{~cm} \times 32 \mathrm{~cm}$ with a capacity about $40 \mathrm{~kg}$ of wet cocoa beans for every cocoa clones, sacks, drying basin and other tools used for sample analysis such as : soxhlet apparatus, oven, excavator, cuvette, analytical measurement, blender, glassware, water bath, vortex, Minolta color reader, spatula, stirrer magnet, sieve measurement 40 mesg, pulverizer and micro pipette.

The raw materials of the research are fermented and non-fermented cocoa beans forestero from Sulawesi 2 clones and local clones. Cocoa pods used for research from cocoa plantation in Batulappa, Pinrang district, South Sulawesi Indonesia. The several types of 
chemicals needed for sample analysis such as methanol, $\mathrm{HCl}$, sterile distilled water, benzene petroleum, filter paper, alcohol, cotton and aluminum foil.

\subsection{Research Procedure}

\subsubsection{Fermented Cocoa Beans}

Fermentation process was carried out for 6 days. Spontaneous fermentation of cocoa beans using styrofoam box $40 \mathrm{~kg}$ with a hole in the bottom of the box was used as aeration and dispose fermentation liquid. Fermentation process of cocoa beans is anaerob and aerob. Anaerob fermentation is carried out for the first 2 days then followed by aerob fermentation for 4 days. Stirring carried out aerobic after 48 hours on the $3-6$ days. Drying of cocoa beans used sun drying for 6-7 days with a long exposure of 7-8 hours per days. Drying is stopped after the water content of the cocoa beans reaches a maximum of $7.5 \%$.

\subsubsection{Sampling}

Samples for analysis were obtained from fermented and non-fermented cocoa beans from Sulawesi 2 clones and local clones. Samples in the form of dried cocoa beans with water content of $\pm 7 \%$ each weighing $\pm 1 \mathrm{~kg}$ were taken 3 times for each clone. Samples were taken on fermentation day 0 (non-fermentation), 2, 4 and 6 , respectively after temperature measurement and before stirring of cocoa beans. Temperature and $\mathrm{pH}$ measurements was done every day until the fermentation process completed.

\subsection{Fermentation Analysis Results}

\subsubsection{Characteristics of Cocoa Beans During Fermentation}

\subsubsection{Wet Cocoa Beans Fermentation Temperature}

The measurement of the temperature from wet cocoa beans is carried out during the fermentation process with interval every 6 hours. Temperature measurement using thermometer plugging the tip of the thermometer in the middle of the container contain cocoa beans.

\subsubsection{Acidity of Cocoa Beans ( $\mathrm{pH}$ )}

$\mathrm{pH}$ testing was carried out on samples of wet cocoa beans non-fermented and fermented at 2, 4 and 6 days used digital $\mathrm{pH}$ meter (PH-009-A) with an accuracy of $0.01 \%$. First step before measure activities is a calibration on the $\mathrm{pH}$ meter. Weigh the test sample about $10 \mathrm{~g}$ into a beaker, then added $90 \mathrm{ml}$ of hot distilled water $\left(70-80^{\circ} \mathrm{C}\right)$, stir gently until a suspension is formed. Filter the suspension and cooling the filtrate to room temperature $\left(27^{\circ} \mathrm{C}\right)$ and determine the $\mathrm{pH}$ of the filtrate as soon as possible the temperature needed (29).

\subsubsection{Total Acid}

Measurement of total titrated acid is carried out by the principle of acid-base titration. A total of $10 \mathrm{~g}$ sample of cocoa beans put into flask diluted in $100 \mathrm{ml}$, then pipetted as much as $25 \mathrm{ml}$ into erlenmeyer. Then added with three drops of phenophaline indicator. Samples were added with $0.1 \mathrm{~N} \mathrm{NaOH}$. Titration was stopped if the color turned pink (30). Calculation of total acid (\%) using formula :

$$
\begin{array}{ll} 
& T A(\%)=\frac{\text { volume } \mathrm{NaOH} \times \mathrm{N} \mathrm{NaOH} \times \mathrm{FP} \times \text { Grek } \times 100}{\text { material weight } \times 1000} \\
\mathrm{~N} \mathrm{naOH} & =0,1 \mathrm{~N} \\
\mathrm{FP} & =\text { Dilution Factor } \\
\text { Grek } & =60
\end{array}
$$




\subsubsection{Physical Characteristics of Dry Cocoa Beans \\ 2.2.2.1. Cut Test}

The test by observing the change in color of the cocoa beans. A total of 200 of cocoa beans are cut into two with longitudinally in the middle with the same size. Then 400 cutting of the cocoa beans were observed one by one based classification the color of the cocoa bean pieces (SNI 01-2323-2008). In this study the classification of cocoa beans divided into 3 classes : unfermented meaning the slaty color (slightly grayish purple and solid textured), unfermented meaning the dominant purple color of cocoa beans and fermented meaning dominant cocoa beans to be brown. The percentages of the three classifications are slaty, violet, and brown was calculated using the formula:

$$
\begin{aligned}
& \% \text { fermented seeds }=\sum \frac{\text { slaty colored halves }}{\text { parts of total cocoa beans }} \times 100 \% \\
& \% \text { fermented seeds }=\sum \frac{\text { purple hemispheres }}{\text { parts of total cocoa beans }} \times 100 \% \\
& \% \text { fermented seeds }=\sum \frac{\text { brown hemisphere }}{\text { parts of total cocoa beans }} \times 100 \%
\end{aligned}
$$

\subsubsection{Color of Dry Cocoa Beans}

Color determination of cocoa beans used Minolta CR-300 Color Reader. Measurements were made at three different points until values of $L^{*}, a^{*}$ and $b^{*}$. The measurement of cocoa beans were made in 3 replicated.

\subsubsection{Chemical Characteristics of Dry Cocoa Beans \\ 2.2.3.1. Water Content}

Water content testing was carried out on samples of dried cocoa beans at nonfermented and and after fermentation with the moisture analyzer method DSH-50-1 with an accuracy of 0.01 .

\subsubsection{Fat Content of the Soxhlet Method}

A sample weighed as much as $2 \mathrm{~g}$ was inserted into a paper sleeve covered with cotton then put in a soxhlet device that connected to a fat flask containing boiled dried rock and known its weight. The sample was extracted with petroleum ether solvent fapproximately 6 hours. Distilled the petroleum ether and dry the fat extract in the oven at $105^{\circ} \mathrm{C}$ for 1 hour, then put into dexicator for 30 minutes and weighed. Repeat drying process until reaches a constant weight and calculate the fat content of the sample (31).

$$
\text { Fat level }(\%)=\frac{\text { Fat weight }(\mathrm{g})}{\text { Sample weightl }(\mathrm{g})} \times 100
$$

\subsection{Statistical Analysis}

The research was conducted a two factorial Randomized Block Design and evaluated by ANOVA and continued with a Duncan Multiple Range Test at level of $5 \%$ to determine differences in mean values and analysis of interactions between treatment factors. The first factor is the treatment of different cocoa clones, there are two levels : cocoa beans Sulawesi 2 clones and local clones. The second factor is the fermentation time treatment in four levels : 0 days fermentation (non-fermentation), 2 days, 4 days and 6 days. Each treatment interaction was repeated in three times. 


\section{Results and Discussion}

\subsection{Characteristics of Cocoa Beans During Fermentation \\ 3.1.1. Seed Temperature During Fermentation}

Temperature is one of the important indicators to determine the success of fermentation process. Fermentation process activities can detected through changes in the fermentation temperature from the beginning to the end of the fermentation period. The temperature of the fermentation is divided into two parts such as anerob and aerob temperature as shown in Figures 1 and 2.

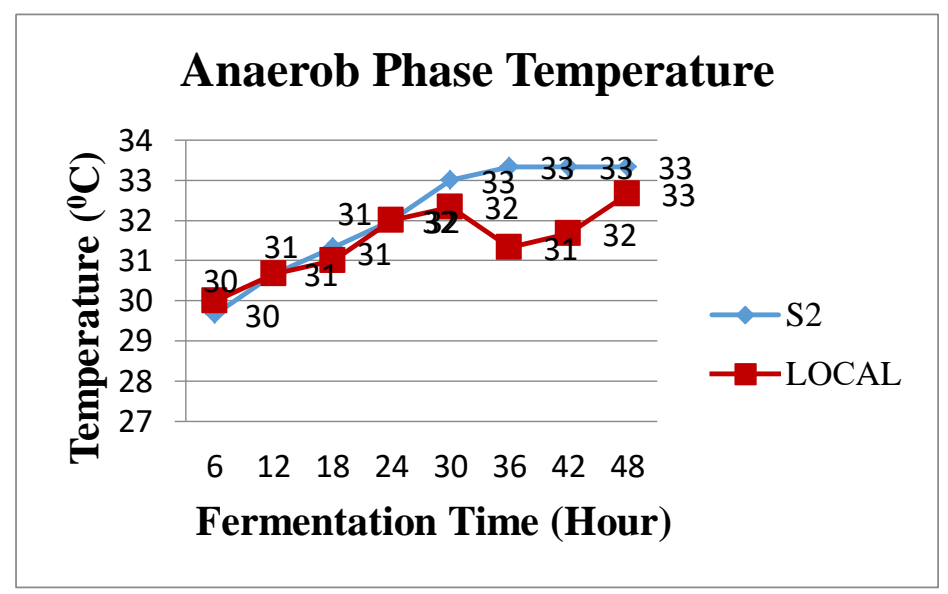

Figure 1. Changes in the temperature of the anaerob phase during fermentation

The temperature of anaerob phase was 48 hours ( 2 days of fermentation). Figure 1 was showed the temperature at $6-48$ hours increased from $30-33^{\circ} \mathrm{C}$ in both Sulawesi 2 and local clones. However, local clones at 36 hours decreased to $31^{\circ} \mathrm{C}$ and increased again at 42 48 hours. The difference of temperature in the anaerob phase is due to chemical reactions that occur by microorganisms. In this phase, yeast will convert the sugar contained in the pulp into pyruvic acid, ethanol and carbon dioxide then release heat in the surface $(28,32)$. Microorganisms playing very important a role in this phase are yeast that grows with temperature optimum 30-35으. According to Sabahannur's research (33) reported that Saccharomyces cerevisiae grows optimally at temperatures around $30^{\circ} \mathrm{C}$ in the anaerob phase. Then Apriyanto (34) reported that $S$. cerevisiae increasing population from $10^{2}-10^{6}$ $\log \mathrm{CFU} / \mathrm{g}$ to $10^{7} \log \mathrm{CFU} / \mathrm{g}$ after fermentation at first of 24 hours. Lactic acid bacteria growed dominantly on the 2 days of fermentation.

Figure 2 was showed the fluctuating temperature from 54-144 hours during the 3 - 6 day of fermentation, starting from the lowest temperature of $35^{\circ} \mathrm{C}$ to the highest temperature of $47^{\circ} \mathrm{C}$. Temperature was showed in Sulawesi 2 and local clones are not much different where every 6 hours there is fluctuation during fermentation. The temperature increasing in the first 6 hours on the 3 - 6 days of fermentation (54, 78, 102 and 126 hours) then decreased until the 18 hours and increasing in 24 hours everyday for 4 days of aerobic phase fermentation. The highest temperature at cocoa beans in local clones about $47^{\circ} \mathrm{C}$ occurred at 102 hours (5 days), whereas in Sulawesi 2 clones the highest cocoa beans temperature occurred at 126 hours ( 6 days) around $46^{\circ} \mathrm{C}$. In contrast to the research of Aryani et al.(28) using wooden boxes obtained an optimum temperature of $45,60^{\circ} \mathrm{C}$ at 60 hours. This is lower than the optimum temperature produced from the Styrofoam container. According to Amin (35), the optimum temperature needed for fermentation of 
cocoa beans in order to obtain good results range in $44-48^{\circ} \mathrm{C}$, which occurs after 48 hours of fermentation process.

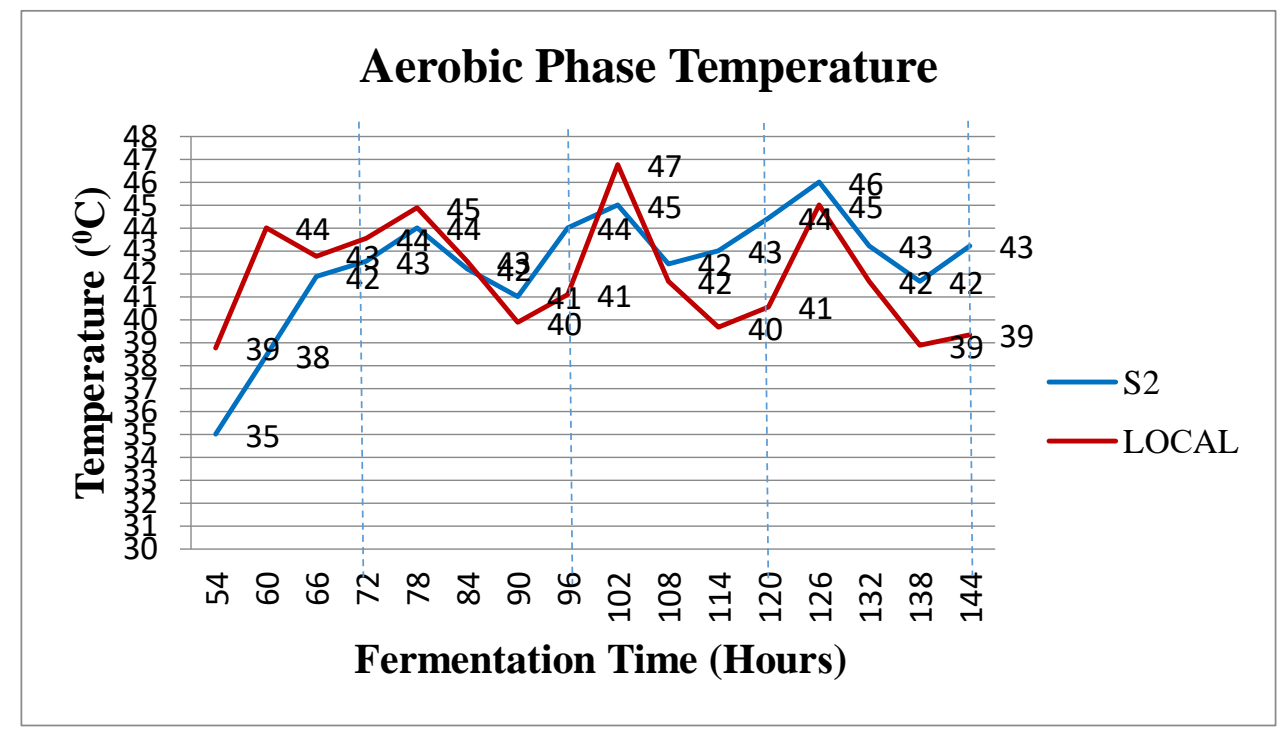

Figure 2. Changes in the temperature of the aerob phase during fermentation

One of important factors causing temperature fluctuation during the aerobic phase is stirring. In this study, stirring of material was carried out every 24 hours after passing through the anaerobic phase. The purpose of stirring material is to equalize fermentation of wet cocoa beans and increase the fermentation temperature. The temperature decrease in the aerobic phase was caused by the heat after stirring. A steady decrease in temperature also allowed the growth of lactic acid bacteria in not optimal condition. Yusianto (36) was explained that stirring process has a significant effect on changes in fermentation temperature and increasing to $45-49^{\circ} \mathrm{C}$ several hours after stirring. The heat increasing during aerobic fermentation was caused the existence of oxidation reactions that require oxygen supply for its survival of microorganism. Tarigan (15) and Wahyudi et al.(37) stated that under aerob conditions, the active acetic acid bacteria oxidize alcohol to acetic acid by releasing a distinctive odor. The activities of bacteria stopped in the temperature of cocoa beans reaching $42-52^{\circ} \mathrm{C}$. Munarso et al.(38) reported that the temperature of cocoa beans during fermentation increasing and reach a maximum after the second day then decrease on the fourth day until the end of fermentation.

\subsubsection{Acidity of Cocoa Beans ( $\mathrm{pH}$ )}

Changes in $\mathrm{pH}$ during fermentation of cocoa beans caused by the presence of microorganism activities and affected the quality of fermentation products. The results of the $\mathrm{pH}$ analysis during fermentation was showed in Figure 3.

Figure 3 was showed the $\mathrm{pH}$ value in cocoa beans decreased during fermentation. Variance results showed that the fermentation time had a significant effect $(P<0.05)$ on the $\mathrm{pH}$ value, while the clone and interaction of both had no significant effect $(P \geq 0.05)$ of the $\mathrm{pH}$ value. The initial $\mathrm{pH}$ of the cocoa beans before fermentation (F0) was 6.2 for local clones and 5.9 for Sulawesi 2 clones which dropped to $\mathrm{pH} 4.8$ and 4.5 on 6 days fermentation. The best of cocoa beans $\mathrm{pH}$ value was found in fermentation on 3 days for Sulawesi 2 clones (5.3) and 4 days at local clones (5.4). In contrast to the study of Aryani et al.(28) the acidity level of the cocoa beans from fermentation treatment with wooden boxes and plastic sacks on 4 days resulted in a fairly low pH value of 4.10. According to Atiqoh (39), the acidity level 
of cocoa beans usually ranges between $\mathrm{pH} 5.0-5.8$. If $\mathrm{pH}>5.8$ means that the fermentation process is less than perfect, while $\mathrm{pH}<5.0$ means the cocoa beans have a high enough acidity. Cocoa pH should not be less than 3.5. The cocoa processing industry requires a cocoa beans pH between 5.2 - 5.8 to produce high quality of cocoa butter (13).

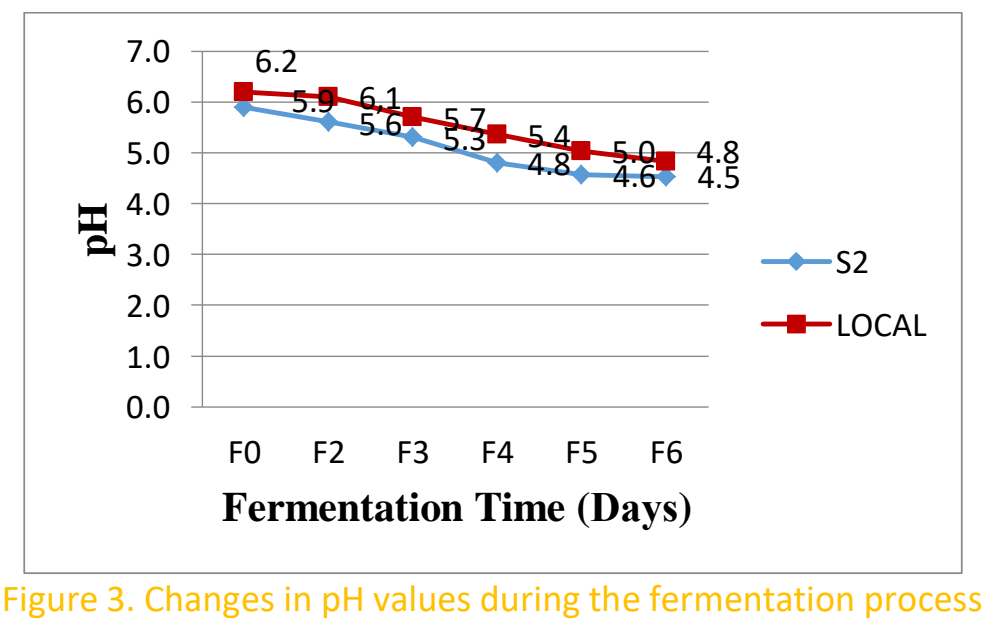

Decrease in cocoa beans $\mathrm{pH}$ caused by the penetration of organic acids such as lactic acid and acetic acid produced by the activity of microorganisms during fermentation into cocoa beans. The microorganism activities made $\mathrm{pH}$ conditions in cocoa beans become more acidic as indicated by a decrease in $\mathrm{pH}$ value (40). According to Purwanto et al.(41) reported that during fermentation, some of the acetic acid evaporates as volatiles material and some of the others enter the cotyledons of cocoa beans. Ethanol and acetic acid that enter the cocoa beans and the heat produced contributes to changes in the subcellular structure of the beans, such as the death of the beans and decrease in $\mathrm{pH}$. This reaction produced compounds of flavor characteristic of chocolate and degradation of pigments by endogenous enzymes, such as : invertase, glycosidase, protease and polyphenol oxidase $(16,19)$.

\subsubsection{Total Acid}

Acid production is important in the fermentation process because the acid diffuse into the cocoa beans then induce biochemical reactions caused fully fermented (34). The total acid yield during fermentation was showed in Figure 4.

The total acid value is inversely proportional to the $\mathrm{pH}$. The higher of the total acid value, the lower $\mathrm{pH}$ value obtained in the ingredients. The analysis of total acid of cocoa beans during fermentation showed the longer of the fermentation time. The higher of average value was showed total acid produced. The results of variance showed that the clone factor giving a very significant difference $(P<0.01)$ to the total acid obtained, but not significantly different $(P \geq 0.05)$ for the length of fermentation and interaction between the factors. The highest total acid in the Sulawesi 2 clone was obtained at 6 days of fermentation at $2.47 \%$ and local clones the highest acid content was produced at 4 days fermentation at $0.90 \%$. The average total acid value in Sulawesi 2 clone was higher than the local clone, $1.69 \%$ for Sulawesi 2 clone and $0.63 \%$ in local clone. 


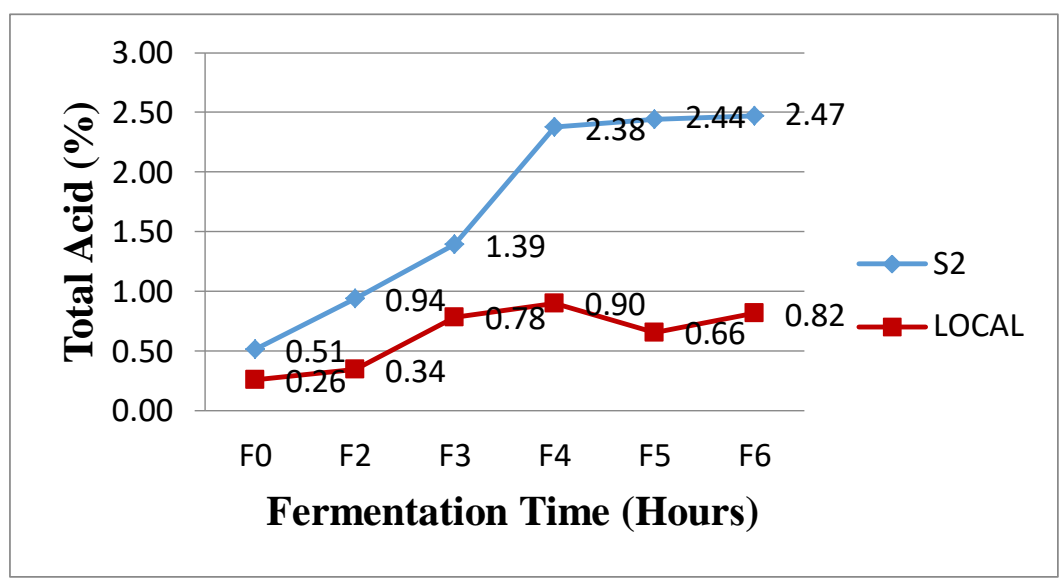

Figure 4. Change in total acid value during fermentation

The increase in total acid is due to the breakdown of alcohol into organic acids as the result of fermentation in the form of acetic and lactic acid. Organic acids are divided into groups of volatile organic acids (acetic acid) and non-volatile organic acids (lactic acid, succinic, malic, oxalate and tartaric) $(33,42,43)$. Wahyudi et al. $(37)$ added that acetic acid is an acid component with the greatest concentration reaching $788 \mu \mathrm{g} / \mathrm{g}$. These organic acids form affected the acidity $(\mathrm{pH})$ of cocoa beans after fermentation (44-46). However, in 5 days fermentation the total acid in local clones was decreased. This is presumably because acidproducing microorganisms decrease or die. According to Fardiaz (47), microorganisms begin to die because several factors such as : nutrients in the medium are depleted or the energy reserves in the cells are depleted.

\subsection{Physical Characteristics of Dry Cocoa Beans 3.2.1 Cut Test}

Based physical characteristic, the fermentation from various samples of cocoa beans was showed from the results of the cut test (split test). Qualitatively success of the fermentation process based the change in the color of cocoa beans. The results of the cocoa bean split test in the study was presented in Figure 5.

On the second day of fermentation the color of the cocoa beans for the two clones began to change from gray to purple brown means the beans started partially ferment (under fermented process) around 56\% for Sulawesi 2 clones and 62\% for local clones. But gray/slaty beans (unfermented) is also still much produced by $37 \%$ and $30 \%$ for $\mathrm{S} 2$ and local clones, respectively. Slaty beans means unfermented seeds that showed half or more of the surface of the slices colour of gray or blue gray beans, solid and unsolid texture (29). Slaty beans will give an astringent and bitter taste excessive and low aroma of cocoa (48). Furthermore, on the 4 day fermentation the beans are still predominantly brownish purple (underfermented) around $60-68 \%$. But the research also produced beans have been fully fermented indicated by changing the color of the cocoa beans to brown by $25 \%$ and $27 \%$ for Sulawesi 2 and local clones, respectively. During fermentation process, polyphenols are oxidized by the polyphenol oxidase enzyme with the help of air to form complex tannin compounds inside beans flow into the skin cause brown of cocoa beans (7). 


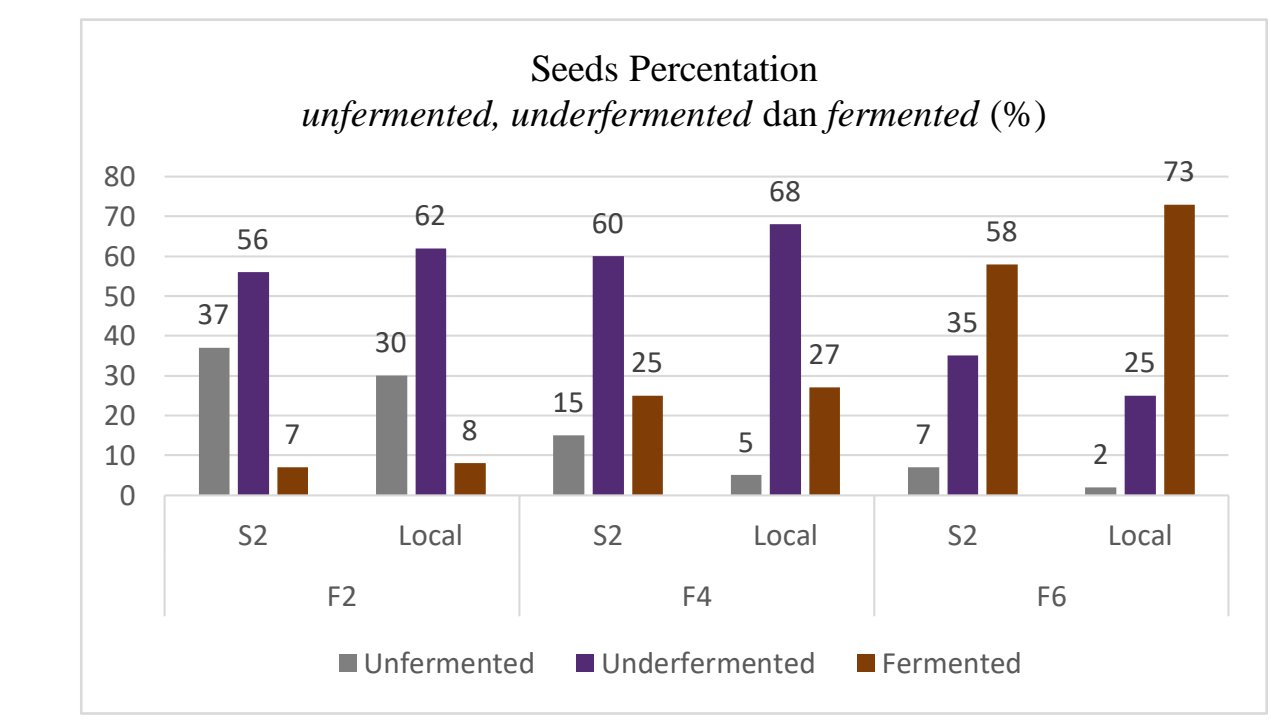

Figure 5. Percentage of unfermented, underfermented and fermented of cocoa beans during fermentation

On the second day of fermentation the color of the cocoa beans for the two clones began to change from gray to purple brown means the beans started partially ferment (under fermented process) around 56\% for Sulawesi 2 clones and 62\% for local clones. But gray/slaty beans (unfermented) is also still much produced by $37 \%$ and $30 \%$ for $\mathrm{S} 2$ and local clones, respectively. Slaty beans means unfermented seeds that showed half or more of the surface of the slices colour of gray or blue gray beans, solid and unsolid texture (29). Slaty beans will give an astringent and bitter taste excessive and low aroma of cocoa (48). Furthermore, on the 4 day fermentation the beans are still predominantly brownish purple (underfermented) around $60-68 \%$. But the research also produced beans have been fully fermented indicated by changing the color of the cocoa beans to brown by $25 \%$ and $27 \%$ for Sulawesi 2 and local clones, respectively. During fermentation process, polyphenols are oxidized by the polyphenol oxidase enzyme with the help of air to form complex tannin compounds inside beans flow into the skin cause brown of cocoa beans (7).

On the 6 days of fermentation, more fermented beans about 58\% and 73\% for Sulawesi 2 and local clones, rerspectively. Fully fermented beans are characterized by the presence of dark brown approximately $80 \%$ of the outer skin and cotyledons then presence of small pores inside the seeds $(37,49)$. Colored under fermented beans showed mixture of purple and brown on the 6 day fermentation is still quite high at $25 \%$ and $35 \%$ for local and Sulawesi 2 clones. Under fermented beans are not considered to damage the taste if the amount is not more than $20 \%$, and still accepted if the amount between $30-40 \%$. If the amount exceeds $50 \%$ will produce a bitter taste (48). There are slaty cocoa beans (unfermented) in both clones around $2-7 \%$ on the 6 days fermentation. The result showed that cocoa beans are not fermented perfect. It is possible that the fermentation process does not occur evenly throughout the cocoa beans, causing slaty beans to be produced on 6 days fermentation (50). Unequal bean condition will produce variations in the quality of fermented beans. The results of the cut-test analysis showed that the fermented cocoa beans in this study still met the quality requirements of cocoa beans (SNI 01-2323-2000). There are showed at the end of the 6 days fermentation about 2\% slaty cocoa beans for local cocoa entered into Quality I (slaty seeds $<3 \%$ ) while $7 \%$ for Sulawesi 2 clones included 
in Quality II (slaty seeds <8\%). This is quite low compared to the number of slaty beans produced from cocoa beans from Soppeng and East Luwu Regencies, respectively $7.67 \%$ and $4.33 \%(42)$.

\section{2 .2 Color}

Color measurements are made after the dried cocoa beans mashed before removing the fat. Color is measured by using a color reader that produces $L^{*}, a^{*}$, and $b^{*}$ values. The difference in color of cocoa beans become powder was showed in Figure 6.

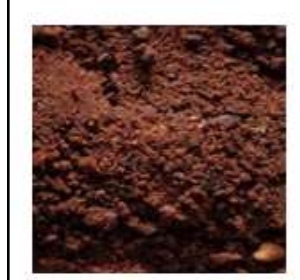

A1:a

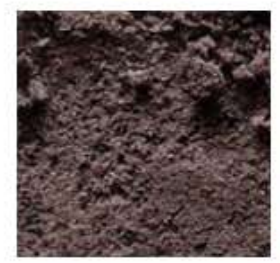

A2.a

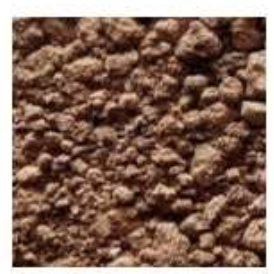

$\mathrm{A} 1 . \mathrm{b}$

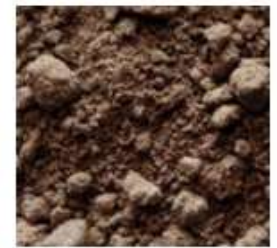

$\mathrm{A} 2, \mathrm{~b}$

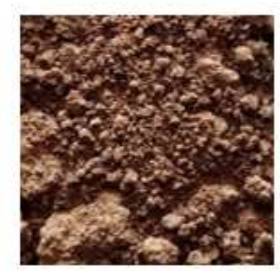

A1.c

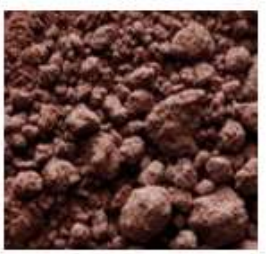

A2.C

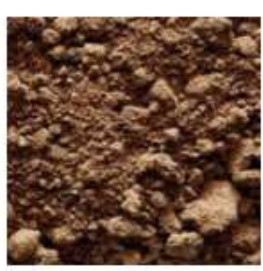

A1.d

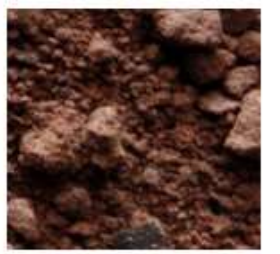

A2, d

\section{Figure 6. Appearance of pulverized cocoa bean samples before removal}

(A1.a: Sulawesi 2 clone cocoa beans fermented 0 days (non-fermented); A1.b: Sulawesi 2 clone cocoa beans fermented in 2 days; A1.c: Sulawesi 2 clone cocoa beans 4 days fermentation; A1.d: Fermented Sulawesi 2 clone cocoa beans 6 days; A2.a: Local clone cocoa beans 0 days (nonfermented); A22.b: Local clone fermented cocoa beans 2 days; A2.c: Local clone cocoa beans fermented 4 days; A2.d: Local clone cocoa beans fermentation in 6 days).

The color of the powder produced on the fermented beans 0 days (non-fermented) both in Sulawesi 2 and local clones brighter than fermented beans. The longer of the fermentation time affect the color of the cocoa powder tends to be darker. Based physical performance, the best color of cocoa powder is produced on 4 days fermentation (A1.C and A2.c) because it has the same color of commonly cocoa powder in commercial scales.

The identification of the color of cocoa powder (values $L$, $a$ and $b$ ) was showed in Table 1 . The results of the color measurements showed the range of $L$ values (lightness) produced on cocoa beans ranged from 54.73 to 69.13 (Table 1). There are indicates the longer of fermentation time, the average color produced tends to be dark. $L$ value (brightness level) shows a significant difference in the color of the cocoa beans produced. In Sulawesi 2 clones, the color of the beans before fermentation (F0) produced a brighter color with an $L$ value of 63.53 compared to 6 days of fermented beans with a fairly dark color with an $L$ value of 55.70. According to Widyotomo et al.(7) reported that 5-6 days fermentation, the brown color will become darker. It is different in local clones where the $L$ at cocoa beans before fermentation is 69.13 decrease until the 4 days fermentation with an $L$ value of 54.73. But on the 6 days fermentation the cocoa beans produce a slightly brighter color compared to the 2 and 4 days fermentation with an $L$ value of 59.07. In general, the dark color produced in cocoa powder is due to the presence of fat content inside, the lower the value of $L$ (lightness) produced indicates the powder fat content is also higher (Table 1 ). 
The factors that playing role in the formation of color are fermentation time and drying time where the decomposition of polyphenol compounds comes out of the cocoa beans. Changes in the composition of polyphenols during fermentation are marked by a reduction in the purple color of the beans with the help of polyphenol oxidase resulting in the color of the cocoa beans (51). Tannin compounds such as flavones and flavan-3-ol are responsible for the formation of various colors of cocoa powder during the drying process (52).

Table 1. Characteristics of Water Content, Fat Content and Color of Cocoa Powder Before Fat Removal

\begin{tabular}{|c|c|c|c|c|c|c|c|c|c|c|}
\hline \multirow{3}{*}{ Treatment } & \multicolumn{6}{|c|}{ Color Identification } & \multirow{2}{*}{\multicolumn{2}{|c|}{$\begin{array}{c}\text { Water content } \\
(\%)\end{array}$}} & \multirow{2}{*}{\multicolumn{2}{|c|}{$\begin{array}{c}\text { Fat content } \\
(\%)\end{array}$}} \\
\hline & \multicolumn{2}{|c|}{$\mathrm{L}$} & \multicolumn{2}{|c|}{$a$} & \multicolumn{2}{|c|}{$b$} & & & & \\
\hline & $\mathrm{A} 1$ & A2 & A1 & A2 & A1 & A2 & A1 & A2 & A1 & A2 \\
\hline F0 & 63.53 & 69.13 & +9.13 & -5.13 & +6.67 & +0.90 & $6.33^{\mathrm{a}}$ & $6.50^{\mathrm{a}}$ & $44.12^{d}$ & $44.10^{d}$ \\
\hline F2 & 60.00 & 55.97 & +3.77 & +3.00 & +9.30 & +6.30 & $5.93^{\mathrm{ab}}$ & $6.03^{a b}$ & $47.41^{\mathrm{c}}$ & $47.46^{c}$ \\
\hline $\mathrm{F} 4$ & 57.50 & 54.73 & +6.67 & +7.17 & +11.07 & +6.73 & $5.40^{\mathrm{bc}}$ & $4.97^{b c}$ & $48.39^{b}$ & $50.45^{\mathrm{b}}$ \\
\hline F6 & 55.70 & 59.07 & +7.33 & +5.97 & +11.40 & +7.87 & $5.23^{c}$ & $5.30^{\mathrm{b}}$ & $51.75^{\mathrm{a}}$ & $52.66^{\mathrm{a}}$ \\
\hline
\end{tabular}

The numbers followed by the same letters are not significantly different according to Duncan's Multiple Range Test at the 5\% level.

A1: Sulawesi 2 clone; A2: local clone; F0: Fermentation time 0 days (non fermentation); F2: Fermentation time in 2 days; F4: Fermentation time in 4 days; F6: Fermentation time in 6 days

$\mathrm{L}=$ lightness

$\mathrm{a}=$ hue $\mathrm{a}+$ : red, $\mathrm{a}-$ : green

$\mathrm{b}=$ intensity, $\mathrm{b}+$ : yellow, $\mathrm{b}-$ : blue

\subsection{Chemical Characteristics of Dry Cocoa Beans \\ 3.3.1 Water Content of Dry Cocoa Beans}

Water content is one of the most important parameters in the cocoa processing because affect the appearance and taste of cocoa beans. The water content obtained in this study range from 4.97-6.50\% (Table 1). In unfermented cocoa beans (F0) the initial water content produced was $6.33 \%$ and $6.50 \%$ for Sulawesi 2 and local clones, respectively. Whereas on fermentation until the 6 days drop to $5.23 \%$ and $5.30 \%$ for Sulawesi 2 and local clones, respectively. The results indicated the water content of the dried cocoa beans produced accordance with the standard because did not exceed the maximum standard set by BSN (29) of 7.5. If the water content of cocoa beans more than $7.5 \%$, there are risk of developing bacteria and fungi. In contrast, the water content less than $5 \%$ made the beans coated break easily or brittle. It means the low quality of cocoa beans and must be separated because they contain high levels of broken beans $(28,37)$.

The results of the diversity analysis showed that the clone factor had a nonsignificant effect $(P \geq 0.05)$ on the water content. While the fermentation time factor has a significant effect $(P<0.05)$ on the water content of cocoa beans. Average water content in cocoa beans decreases with the length of the fermentation process. This is according to Marwati's research (53) which obtained lower water content at the end of fermentation. The decrease in water content caused by the release of pulp in the cocoa beans due to the process of decomposition by microbes during the fermentation process. The content of the material in the cocoa beans such as water, polyphenols and proteins will rupture and diffuse out of the seed keeping. The weight level of the beans is reduced and facilitate the drying 
process. In addition, during the fermentation process, beans will death and result in the semipermeability of the cell wall to be damaged then facilitate the release of water during the drying process (54).

The water content of cocoa beans also influenced by the duration of drying. In this study, drying is naturally with presence of sunlight for 5-7 days. To reach water levels below $7.5 \%$ depends on the intensity of sunlight (8). Winarno (55) reported the drying process is strongly influenced by temperature and time of process. Drying with temperatures too high resulted uneven drying such as the outside is dry, while the inside still contains a lot of water. The longer of the drying process is carried out, the amount of water is evaporated in food will be more and the measured water content will be low.

\subsubsection{Fat Levels}

Fat is the most expensive component contain in the cocoa beans. The content of cocoa fat was influenced by planting material and season, as well as processing treatment (56). The fat content of fermented cocoa beans ranges from $44.10-52.66 \%$. The results of variance indicate that the cocoa clone factor has a significant effect $(P<0.05)$ on the level of seed fat produced, while the fermentation time factor has a very significant effect $(P<0.01)$ and the interaction of both has no significant effect $(P \geq 0.05)$. Although the cocoa clone factor has a significant effect on fat content, the difference in fat content values for the two types of clones is relatively small. The average fat content in the Sulawesi 2 clone is lower than the local clone. According to Mulato et al.(19) cocoa beans derived from plants grown in the rainy season generally have high fat content. Physical characteristics of postprocessing cocoa beans, such as water content, fermentation levels and skin levels, affect the fat yield of cocoa beans. In the 6 days fermentation, the highest fat content was $51.75 \%$ and $52.66 \%$ for Sulawesi 2 and local clones, respectively. While the lowest fat content obtained in cocoa beans before fermentation (F0) was $44.12 \%$ and $44.10 \%$ for Sulawesi 2 and local clones, respectively (Table 1). Findings of research showed that the longer of the fermentation time result the higher average fat content of beans dried cocoa produced. Research by Ristanti et al.(25) and Sabahannur et al.(42) obtained the highest fat content from cocoa beans from Pinrang Regency which was only $38.21 \%$, followed by Bulukumba at $35.74 \%$ and Palopo at $35.17 \%$, fat content from other regions is only in the range of $20-27 \%$.

In the fermentation process there is a decrease in the content of non-fat materials such as : protein, polyphenols and carbohydrates that decompose, in contrast fat content will increase. Also during the fermentation process the formation of aldehydes, ketones, alcohols, esters release as the volatile material $(16,57,58)$. Increased levels of cocoa bean fat are also affected by drying time, where the longer the drying time the water content decreases because only evaporates water and a number of volatile compounds but does not evaporate fat (59). Dried cocoa beans are fermented 4 and 6 days is a good category of cocoa beans for further processing because produces a fat content of more than $48 \%$. Where the range of fat content of Indonesian cocoa beans is $48-52 \%$ (19). Puslitkoka (60) requires a fat content of $50-51 \%$ for cocoa beans used as raw material for chocolate products.

\section{Conclusions}

The results was showed that cocoa beans from local clones from Pinrang district were better than Sulawesi 2 clones based on the quality characteristics of the seeds produced. The treatment of cocoa beans from local clones fermented for 4-5 days is a combination of 
treatments that produces the best characteristics of cocoa beans with a cleaner physical appearance and fairly bright color, beans with high fat content and low water content. The cut test result was showed slaty beans were still found at the end of fermentation both of the clones. The possibility of the fermentation process occurring unevenly throughout the cocoa beans. It suspected that the use of styrofoam as a fermentation container caused the heat during fermentation not well circulated. The fermented cocoa beans in this study still meet the quality requirements of cocoa beans (SNI 01-2323-2000), namely Quality I for local clones and Quality II for Sulawesi 2 clones. The use of styrofoam can be used as an alternative besides fermentation with wooden boxes that are usually done by farmers so far. In addition, local clone cocoa beans from Pinrang Regency from this study have higher fat content compared to cocoa beans from other districts in South Sulawesi.

\section{Acknowledgements}

We would like to say thank you very much to the Indonesian Agency of Agricultural Research and Development for providing financial assistance for this research activity.

\section{References}

1. Direktorat Jenderal Perkebunan. Statistik Perkebunan Indonesia 2014-2016, Kakao. Direktorat Jenderal Perkebunan,Kementerian Pertanian, Jakarta. 2015.

2. Rubiyo, Siswanto. Peningkatan Produksi dan Pengembangan Kakao (Theobroma cacao L.) di Indonesia. Buletin RISTRI. 2012;3(1).

3. Widayat HP. Perbaikan mutu bubuk kakao melalui proses ekstraksi lemak dan alkalisasi. Jurnal Teknologi dan Industri Pertanian Indonesia. 2013;5(2): 12-16.

4. Munarso SJ, Miskiyah. Penerapan sistem HACCP pada penanganan pascapanen kakao rakyat. Jurnal Standardisasi. 2014;16(1): 17-30.

5. Indarti E, Arpi N, Budijanto S. Kajian pembuatan cokelat batang dengan metode tempering dan tanpa tempering. Jurnal Teknologi dan Industri Pertanian Indonesia. 2013;5(1):1-6.

6. David J, Yusuf RP, Yudari DAS. Pengaruh cara pengolahan kakao fermentasi dan non fermentasi terhadap kualitas, harga jual produk pada unit usaha produktif (UUP) Tunjung Sari Kabupaten Tabanan. E-Jurnal Agribisnis dan Agrowisata. 2013;2(4): 191203.

7. Widyotomo S, Mulato S, Handaka. Mengenal Lebih Dalam Teknologi Pengolahan Biji Kakao. Warta Penelitian dan Pengembangan Pertanian. 2004;26: (2).

8. Hatmi RU, Rustijarno S. Teknologi Pengolahan Biji Kakao Menuju SNI Biji Kakao 012323-2008. BPTP Yogyakarta. 2012.

9. Hayati R, Yusmanizar, Mustafril, Fauzi H.Kajian Fermentasi dan Suhu Pengeringan pada Mutu Kakao (Theobroma cacao L.). Jurnal Keteknikan Pertanian. 2012;26(2): 129-135.

10. Di Mattia CD, Sacchetti G, Mastrocola D, Serafini M. From cocoa to chocolate: The impact of processing on in vitro antioxidant activity and the effects of chocolate on antioxidant markers in vivo. Frontiers in Immunology. 2017;8:1-7. Available from: http://doi.org/10.3389/fimmu.2017.01207

11. Widyotomo S. Teknologi fermentasi dan diversifikasi pulp kakao menjadi produk yang bermutu dan bernilai tambah. Warta Review Penelitian Kopi dan Kakao. 2008;24:65-82. 
12. Towaha J, Anggraini DA, Rubiyo. Keragaan mutu biji kakao dan produk turunannya pada berbagai tingkat fermentasi: studi kasus di Tabanan Bali. Pelita Perkebunan. 2012;28:166-183.

13. Widianto D, Pranita AD, Wedhastri S. Perbaikan proses fermentasi biji kakao kering dengan penambahan tetes tebu, khamir dan bakteri asam asetat. Jurnal Teknosains. 2013;3(1): 38-44.

14. Rahmi F, Zulfahrizal, Kiman S. Analisis pindah panas pada ruang fermentasi biji kakao (Theobroma cacao L.) dengan menggunakan kotak kayu dan styrofoam. Jurnal Rona Teknik Pertanian. 2017;10(1):34-45.

15. Tarigan EB, Tajul I. Beberapa komponen fisikokimia kakao fermentasi dan non fermentasi. Jurnal Agroindustri. 2017;3(1): 48-62.

16. Camu N, Winter TD, Addo SK, Takrama JS, Bernart H, Vuyst LD. Fermentation of cocoa beans: influence of microbial activities and polyphenol concentrations on the flavour of chocolate. Journal of the Science of Food and Agriculture. 2008;88: 22882297.

17. Afoakwa EO, Payterson A, Fowler M, Ryan A. Flavor formation and character in cocoa and chocolate: a critical review. Critical Reviews in Food Science and Nutrition. 2008;48: 840-857.

18. Afoakwa EO, Jennifer $Q$, Agnes SB, Jemmy ST, Fribu KS. Influence of pulp preconditioning and fermentation on fermentative quality and appearance of Ghanaian cocoa (Theobroma cacao) beans. International Food Research Journal. 2012;19: 127-133.

19. Mulato S, Widyotomo S, Misnawi, Suharyanto E. Pengolahan Produk Primer dan Sekunder Kakao. Pusat Penelitian Kopi dan Kakao Indonesia, Jember. 2005.

20. Indarti E, Widayat HP, Zuhri N. Effect of fermentation container and thickness of bean mass during fermentation process of cocoa bean (Theobroma cocoa L.). Proceedings: Annual International Conference, Syiah Kuala University, Muchlisin (Ed.). 2011;64-69.

21. Retno U, Sinung R. Teknologi Pengolahan Biji Kakao Menuju SNI Biji Kakao 01-23232008. Yogyakarta:BPTP Yogyakarta. 2012.

22. Iflah T, Towaha J. Perbedaan tingkat kematangan buah dan lama pemeraman terhadap kualitas biji kakao. Warta Penelitian dan Pengembangan Tanaman Industri, 2015;21(3): 1417.

23. Managanta A, Sumardjo, Sadono D, Prabowo T. Faktor-Faktor yang Berpengaruh terhadap Kompetensi Petani Kakao di Provinsi Sulawesi Tengah. Jurnal Penyuluhan. 2019;15(1).

24. Martono B. Karakteristik Morfologi dan Kegiatan Plasma Nutfah Tanaman Kakao, Bunga Rampai: Inovasi Teknologi Bioindustri Kakao. 2009;15-28. Available from: http://balittri.litbang.pertanian.go.id/index.php/publikasi/category/94-bungarampai-bioindustri-kakao?download=332\%3A02a.-karakteristik-morfologi-dankegiatan-plasma-nutfah-tanaman-kakao_edit-lila-ok-18-sept

25. Ristanti EK, Suprapti, Aggraeni D. Karakteristik Komposisi Asam Lemak Pada Biji Kakao Dari 12 Daerah Di Sulawesi Selatan. Jurnal Industri Hasil Perkebunan. 2016;11(1)15-22. 
26. Ginting S. Mempelajari Pengaruh Lama Fermentasi dan Lama Penyangraian Biji Kakao Terhadap Mutu Bubuk Kakao. Program Studi Ilmu dan Teknologi Pangan, Fakultas Pertanian Universitas Quality Medan, Medan. 2011.

27. Putra GG, Sutardi S, Kartika B. Peranan Perubahan Komponen Prekursor Aroma dan Cita Rasa Biji Kakao Selama Fermentasi Terhadap Cita Rasa Bubuk Kakao yang Dihasilkan. Agritech. 2017;13(4), 13-17.

28. Aryani NL, Yulianti NL, Arda G. Karakteristik biji kakao hasil fermentasi kapasitas kecil dengan jenis wadah dan lama fermentasi berbeda. Jurnal Biosistem dan Teknik Pertanian. 2018;6(1). Available from: http://ojs.unud.ac.id/index.php/beta

29. BSN (Badan Standarisasi Nasional). SNI 2323 : 2008. Biji Kakao. ICS.67.140.30. 2008.

30. AOAC. Official Method of Analysis. $16^{\text {th }}$ Edition. Association of Official Analytical Chemistry International, Gaithersburg. 1995.

31. AOAC. Official Method. Association of Official Analytical Chemistry (AOAC). 2005.

32. Kustyawati ME, Setyani S. Pengaruh penambahan inokulum campuran terhadap perubahan kimia dan mikrobiologi selama fermentasi coklat. Jurnal Teknologi Industri dan Hasil Pertanian. 2008;13(2).

33. Sabahannur S, Andi R. Peningkatan kadar alkohol, asam dan polifenol limbah cairan pulp biji kakao dengan penambahan sukrosa dan ragi. Jurnal Industri Hasil Perkebunan. 2018;13(1):53-61.

34. Apriyanto $M$, Sutardi S, Supriyanto S, Eni H. Fermentasi biji kakao kering menggunakan Saccharomyces cerevisiae, Lactobacillus lactis dan Acetobacter aceti. Agritech. 2017;37(3): 302-311.

35. Amin S. Teknologi Pascapanen Kakao untuk Masyarakat Perkakaoan Indonesia. Jakarta: Badan Pengkajian dan Penerapan Teknologi. 2005.

36. Yusianto. Teknik Pra Pengolahan Biji Kakao Segar Secara Mekanis untuk Mempersingkat Waktu Fermentasi dan Menurunkan Keasaman Biji. Makalah Seminar Evaluasi Hasil Penelitian ALSINTAN, Bogor. 1998.

37. Wahyudi T, Panggabean TR, Pujiyanto. Kakao, Manajemen Agribisnis Dari Hulu Hingga Hilir. Penebar Swadaya, Jakarta. 2013.

38. Munarso J, Dewandari KT, Haifa Z. Pengaruh penambahan starter mikroba serta pemerasan pulp terhadap kondisi fermentasi dan mutu biji kakao (Theobroma cacao L). Jurnal Penelitian Pascapanen Pertanian. 2016;13(3) : 156-166.

39. Atiqoh I. Isolasi Bakteri Asam Laktat Penghasil Senyawa Antikapang pada Fermentasi Kakao. [Skripsi]. Universitas Jember, Jember. 2007.

40. Karinawantika El. Karakteristik Fisik dan Kimia Biji Kakao Hasil Fermentasi Dalam Wadah Karung Plastik di Pusat Penelitian Kopi dan Kakao Indonesia.[Skripsi]. Fakultas Teknologi Pertanian, Universitas Jember, Jember. 2015.

41. Purwanto EH, Setyabudi S, Supriyanto. Microbial activities in cocoa (Theobroma cacao L.) pulp during fermentation with ragi tape addition. Journal of Industrial and Beverage Crop. 2019;6(1); 21-32. Available from: dx.doi.org/10.21082/jtidp.v6n1.2019.p21-32

42. Sabahannur S, Nirwana. Kajian pengaruh berat biji kakao perkotak dan waktu pengadukan terhadap keberhasilan proses fermentasi. Jurnal Pendidikan Matematika dan IPA. 2017;8(2)18-30.

43. Jinap S, Dimick PS. Effect of roasting on acidic characteristics of coco Beans. Journal of the Science of Food Agriculture. 1991;54. 
44. Guehi TS, Dadie AT, Koffi KPB, Dabonne S, Ban-Koffi L, Kedjebo KD, Nemlin GJ. (2010). Performance of different fermentation methods and the effect of their duration on the quality of raw cocoa beans. International Journal of Food Science and Technology. 2010;45 (12): 2508-2514.

45. Pasau C. Efektivitas penggunaan asam asetat pada pemeraman biji kakao segar sebagai analog fermentasi. E-journal Agrotekbis. 2013;1(2): 113-120.

46. Ramlah S, Daud D. Pengaruh lama fermentasi terhadap warna dan citarasa biji kakao. Jurnal Industri Hasil Perkebunan. 2009;4(1): 24-30.

47. Fardiaz S. Mikrobiologi Pangan. Pusat Antar Universitas Pangan dan Gizi, Institut Pertanian Bogor.1989.

48. Misnawi. Physico-chemical changes during cocoa fermentation and key enzymes involved. Review Penelitian Kopi dan Kakao. 2008;24(1): 47-64.

49. SCCP. Pasca Panen, Pengolahan Biji Kakao Dan Fermentasi. Swiss Foundation for Technical Cooperation. 2013.

50. Ariyanti M. Karakteristik mutu biji kakao (Theobroma cacao L.) dengan perlakuan waktu fermentasi berdasar SNI 2323-2008. Jurnal Industri Hasil Perkebunan. 2017; 12(1): 34-42.

51. Puziah HS. Cocoa Fermentation. Pusat Penelitian Kopi dan Kakao Indonesia. Jember. 2005.

52. Bonvehi JS, Coll FV. Factor affecting the formation of alkylpyrazines during roasting treatment in natural and alkalized cocoa powder. Journal of Agricultural and Food Chemistry. 2002;50: 3743-3750.

53. Marwati. Pengaruh Lama Fermentasi Terhadap Mutu Biji Kakao (Theobroma cacao L) yang Dihasilkan Petani Kakao di Teluk Kedondong Bayur Samarinda. Prosiding Seminar Nasional Kimia. ISBN: 978-60219421-0-9. 2013;218-222.

54. Permana $M$, Sudjatha $W$, Martini Y. Pengaruh Lama Penyimpanan Buah dan Lama Fermentasi terhadap Mutu Biji Kakao Kering. Jurnal Teknologi Hasil Pertanian Denpasar. 1997;3(1).

55. Winarno FG. Kimia Pangan dan Gizi . Gramedia Pustaka Utama. Jakarta. 1997.

56. Langkong J, Ishak E, Bilang M, Muhidong J. Pemetaan Lemak dari Biji Kakao (Theobroma cacao L.) di Sulawesi Selatan. Universitas Hasanuddin, Makassar. 2012.

57. De Brito ES, Garcia NHP, Gallao MI, Cortelazzo AL, Fevereiro PS, Braga MR. Structural and chemical changes in cocoa (Theobroma cacao L.) during fermentation, drying and roasting. Journal of the Science of Food and Agriculture. 2000;81: 281288.

58. Campos JR, Buendia HBE, Ramos SMC, Avila IO, Flores EJ, Cervantes EL. Effect of fermentation time and drying temperature on volatile compounds in cocoa. Food Chemistry. 2012;132: 277-288.

59. Lutfiah A, Saloko S, Sulastri. Pengaruh Lama Pengeringan Biji Kakao (T Heobroma Cacao L. ) Dengan Alat Pengering Cabinet Driyer Terhadap Mutu Biji Kakao. [Skripsi]. Fakultas Teknologi Pangan dan Agroindustri Universitas Mataram. 2018.

60. Puslitkoka . Pengolahan Produk Primer dan Sekunder Kakao. Pusat Penelitian Kopi dan Kakao Indonesia. 2008. 